GOMES, Ângela de Castro; FERREIRA, Jorge.

\title{
1964: o golpe que derrubou um presidente, pôs fim ao regime democrático \\ e instituiu a ditadura no Brasil
}

Rio de Janeiro: Civilização Brasileira, 2014. 436p.

\author{
Antonio Torres Montenegro \\ Programa de Pós-Graduação em História, \\ Universidade Federal de Pernambuco \\ Campus Recife, Avenida Acadêmico Hélio Ramos S/N $10^{\circ}$ andar CFCH. \\ Cidade Universitária, Recife, PE, 50.670-901, Brasil \\ montenegroantonio084@gmail.com
}

Os historiadores Ângela de Castro Gomes e Jorge Ferreira trazem a publico um livro emblemático, 1964: o golpe que derrubou um presidente, pôs fim ao regime democrático e instituiu a ditadura no Brasil, no ano em que meio século se passou daquele 31 de março. Por meio de uma escrita que captura o leitor desde as primeiras páginas, rapidamente se é tomado por uma curiosidade crescente sobre o relato seguinte, o passo seguinte, a negociação, o cenário. Como a mirar um caleidoscópio, os eventos são narrados alternando temporalidades e espacialidades articulados a um grande domínio das informações bibliográficas e documentais. E não poderia ser diferente, a obra é resultado de uma vida de pesquisa e escritas de livros e artigos, de dois historiadores que muito produziram sobre essa temática e esse período. $\mathrm{O}$ enorme conhecimento sobre a documentação e a bibliografia relacionada à temática e ao período é elemento decisivo que potencializa essa capacidade de pensar a arquitetura da escrita em seus múltiplos vórtices de efeitos de verdade.

Recebido 29 de outubro de 2014 | Aprovado 13 de dezembro de 2014 http://dx.doi.org/10.1590/0104-87752015000100014 Varia Historia, Belo Horizonte, vol. 31, n. 55, p. 299-302, jan/abr 2015 
O livro narra um curto período da história política do Brasil: da crise da renúncia de Janio Quadros, em agosto de 1961, até o golpe civil militar de 1964. No entanto, as dimensões sociais, econômicas e culturais se entrelaçam à narrativa quer no detalhamento das lutas sindicais e de setores da sociedade civil, quer nas tensas negociações das estratégias econômicas, quer nas campanhas da UNE e de defensores de uma reforma educacional ampla, entre outros aspectos abordados.

A narrativa das histórias, eventos e acontecimentos associada à reprodução das notícias de jornais, discursos, declarações, entrevistas se constitui em uma das marcas indeléveis do livro. Os autores, ao recuperarem e atualizarem essa arte de contar, por meio de um estilo que atende a modulações próprias dos múltiplos embates sociais, políticos e econômicos, trilhados ao longo do texto, não se furtam ao desafio metodológico próprio do fazer historiográfico.

E o deslocamento analítico escolhido será projetado na ruptura com uma das práticas de escritura histórica mais contumazes, a busca das origens e a perspectiva teleológica. Não realizar a leitura do pasado, centrada nesta lógica alicerçada em significados e sentidos considerados evidentes e reais, presentes em documentos e na própria historiografia, significa devolver à narrativa histórica a complexidade do operar social e político.Mesmo para muitos de nós que lemos, pesquisamos, escrevemos sobre essa temática, a forma de Angela de Castro Gomes e Jorge Ferreira pensarem e escreverem a história, reconstrói e recupera a incerteza e o acaso das lutas. E dessa maneira, retira a história do perigoso dilema de produtora de mitos, heróis e lugares de memória, instituindo a crítica e a reescritura como seu modus operandi. Afinal a história é história do presente, escrita e reescrita com perguntas, dúvidas que as novas experiências cotidianas apresentam, e que, formuladas ao passado histórico, associam-se a possíveis novas coleções documentais e a sua releitura. Por outro lado, todo esse deslocamento de resignificação, realizado no livro é indissociável das formulações teóricas e metodológicas que lhe garantem transcender a história cronológica e apenas factual.

No entanto, este projeto metodológico abraçado pelos autores é desafiado em algumas passagens ao fazerem uso de citações da historiografia 
ou de relatos de entrevistados que, décadas posteriores, relembram acontecimentos vivenciados no período em estudo no livro. Nessas passagens, lemos citações historiográficas e relatos de memória acerca do golpe de 1964 e de acontecimentos que o antecederam, inteiramente marcados por uma perspectiva determinista em que os signos da derrota e do fracasso se constituem referencias fundadoras à leitura daquele passado histórico. Em face desse desafio vivenciado pelos autores, recordo uma entrevista de Michel Foucault, no livro Repensar a Política, em que lhe é perguntado se "o exercício de uma reflexão teórica está sempre ligado a uma elaboração particular do material histórico?” (2014, p.328). E Foucault, em sua resposta, comenta a dificuldade em utilizar determinadas referências historiográficas, pois elas contemplam outra forma de análise histórica.Talvez este tenha sido um dos maiores desafios dos autores, em face do paradoxo de uma perspectiva teórica e metodológica em dissonância com relatos de memória e a própria historiografia.

Nesse aspecto, é importante reafirmar, que a difícil desconstrução historiográfica foi possível na medida em que o deslocamento analítico se alicerça no domínio da historiografia e de uma vasta e diversificada documentação. Esta é a base deste livro, e o transforma em referência para os historiadores e para o público mais amplo. Sem dúvida, mais uma das virtudes desta obra que, sem perder o rigor próprio à operação historiográfica, é escrita numa linguagem acessível a leitores não especialistas. Assim, um tema e um período crucial para a história do Brasil são narrados de forma acessível e, dessa maneira, o livro concorre para desfazer mitos e discursos arraigados em preconceitos difundidos diuturnamente em amplos segmentos da sociedade.

Embora consciente de que uma resenha é uma leitura e toda obra está aberta a múltiplas releituras, assinalo a emoção como dimensão presente em inúmeras passagens do livro. Emoção que se desdobra em sentimentos de alegria, de revolta, de indignação, de profunda tristeza. Esta é uma das qualidades da escrita dos autores, em que a composição narrativa aparece tecida na produção historiográfica e não determinada $a$ priori, pois é possível obsevar como o estilo do relato adquire ritmos diferenciados, algumas vezes, fazendo relembrar um roteiro cinematográfico. 
O livro de Ângela de Castro Gomes e Jorge Ferreira, ao analisar um tema político da maior importância para a nossa contemporaneidade, atualiza-o no presente e estabelece uma ruptura com um passado atrelado a linearidades e teleologias, projetando os personagens políticos em cenários múltiplos, não mais pensados no enquadramento de dualidades maniqueístas. Dessa maneira, esta obra demarca uma desconstrução de mitos e memórias reificadas, reafirmando a crítica como indissociável do fazer historiográfico.

\section{Agradecimentos}

$\mathrm{O}$ autor, pesquisador nível $1 \mathrm{~B}$, agradece ao $\mathrm{CNPq}$. 